\title{
Heroes and Representations of Masculinity in Thai Action Films
}

\author{
Natawan Wongchalard \\ (นตวัน วงศฉลาด) \\ Lecturer, English Department, Faculty of Humanities, Chiang Mai \\ University, Chiang Mai, Thailand \\ garamchay@gmail.com
}

\begin{abstract}
This paper contextualises a cultural construction of hegemonic masculinity and discusses ways in which Thai action film heroes in historical and Muay Thai films are represented. Traditionally, the quality of nakleng is desirable for Thai action heroes along with having mastery in a particular skill. In the moral realm, the idea of gratitude or khwam-katanyu in Thai, is prioritised and highly regarded to be the inevitable requisite for good men, which includes action heroes. This sense of gratitude extends to one's ideological obligations to one's motherland or matuphum, which is often thematically portrayed in Muay Thai and historical films through the struggle of the hero. Based on a reading of the two exemplar films, Ong Bak (Muay Thai Warrior 2003, dir. Prachya Pinkaew) and The Legend of King Naresuan: The Elephant Duel (2014, dir. Chatri Chalerm Yukol), the different social backgrounds of the two heroes, their hegemonic masculinity, autonomy and lack can be explained in relation to the discourse of Buddhist spirituality. In addition, the ways in which the two heroes are differently depicted is a cinematic device with the aid of which, in addition to the observance of filmic verisimilitude, the representations are designed to cater to segmented subject/citizen audiences. In psychoanalytic terms, each hero from the two films is similarly made to acquire autonomy and experience 'lack' in different realms of the symbolic order.
\end{abstract}

\section{Keywords}

masculinity - gratitude - autonomy - lack - symbolic order 


\section{บทคัดย่อ}

\section{พระเอกและภาพแทนความเป็นชาย ในภาพยนตร์แอคชั่นไทย}

บทความนี้ศึกษาบริบทการสร้างวัฒนธรรมความเป็นชายเชิงอำนาจ และอภิปราย วิธีการการนำเสนอ ภาพแทนของพระเอกในภาพยนตร์แอคชั่นเชิงประวัติศาสตร์ และมวยไทยตามขนบของภาพยนตร์แอคชั่นไทย ลักษณะความเป็นพระเอกที่พึง ปรารถนาต้องประกอบด้วยความเป็นนักเลงและความสามารถเชิงทักษะเฉพาะบาง ประการ นอกจากนี้ พระเอกยังต้องมีคุณธรรมคือความกตัญญเป็นที่ตั้ง ซึ่งหมาย รวมถึงความกตัญญต่อทั้งผู้มีพระคุณและความกตัญญเชิงอุดมการณ์ต่อมาตุภูมิ ลักษณะความกตัญญดังกล้าวถือเป็นคุณลักษณะพื้นฐานของความเป็นพระเอก ซึ่ง มักจะนำเสนอเป็นแก่นเรื่องผ่านการต่อสู้ของเขาในภาพยนตร์แอคชั่น จากการ วิเคราะห์ภาพยนตร์แอคชั่นสองเรื่อง คือ องคบาก (ปี 2546 กำกับโดย ปรัชญา ปี่น แก้ว) และตำนานสมเด็จพระนเรศวรมหาราช ตอนยุทธหัตถี (ปี 2557 กำกับโดย ม.จ. ชาตรีเฉลิม ยุคล) พบว่าความเป็นชายเชิงอำนาจ อัตตาณัติ และความขาดพร่อง ของพระเอกจากภาพยนตร์ทั้งสองเรื่องที่แม้จะมีภูมิหลังทางสังคมที่แตกต่างกัน ต่างมีความเกี่ยวโยงกับวาทกรรมจิตวิญญาณทางพุทธศาสนาเหมือนกัน นอกจาก นี้ การนำเสนอภาพของพระเอกทั้งสองให้ต่างกันถือเป็นวิธีการทางภาพยนตร์เพื่อ ทำให้เกิดความสมจริง ขณะเดียวกันก็ให้ความสำคัญกับผู้ชมกลุ่มต่างๆ ในฐานะ ราษฎร/พลเมือง เมื่อมองในมุมจิตวิเคราะห์ ภายใต้วาทกรรมความเชื่อทางพุทธ ศาสนา พระเอกจากภาพยนตรทั้งสองเรื่องต่างเข้าถึงอัตตาณัติและสัมผัสความขาด พร่องในปริมณฑลแห่งโลกสัญญะที่ต่างกัน

Studies of Thai action films have often been associated with the contentious notion of nationalism ${ }^{2}$ (Kitiarsa 2007; Hunt 2005; Sungsri 2004; Lewis 2003). They have shown us how nationalism is projected on screen and how it addresses the audience. However, given its historical specificity, the concept of nationalism is mutable. In other words, it may be viewed variably depending on the socio-political factors of a particular milieu. For example, against the backdrop of the 1997 economic crisis, popularly known as the Tom Yum Goong crisis, nationalism is read as a reaction against foreign business take-overs and

1 This article is adapted from a chapter of the doctoral dissertation entitled "Contemporary Thai Action Cinema: Genre, Spectatorship and National Identity", submitted to the English and Foreign Languages University, Hyderabad, India.

2 In this study, the term 'nationalism' is used in a non-strict fashion, not being attached to any particular political doctrine. It is referred to firstly, as one's sentiment of belonging to a nation and secondly, a set of values and practices that function to uphold national ideals. 
an appropriation of the self -sufficiency philosophy (Lewis 2003), a self- assertion of Thai identity and cultural ambivalence (Harrison 2005; Hunt 2005) and a projection of Thai masculinity to the world (Kitiarsa 2007). Among these analyses, the idea of nationalism vis-à-vis masculinity is my interest and is thus the main focus of this article. The main reason is that in Thai action films, since the early period of Thai cinema, action heroes have been linked to the national ideology and masculinity in one way or another. However, it is the former relation that has received much scholarly attention. The subject matter of masculinity in action cinema has not been seriously studied until recently. It is expected, thus, that this study will contribute to the meager existing scholarship relating to masculinity in Thai action films.

The question, then, to ask is "What is hegemonic masculinity?", given that the concept of masculinity, per se, can be variable rather than elusive. Following Donaldson (1993), the notion of hegemonic masculinity is derived from a social perception of the normative attributes of men as proposed by Patricia Sexton (1970 cited in Donaldson 1993); for instance, courage, inner direction, certain forms of aggression, autonomy, mastery, technological skill, group solidarity, adventure and considerable amounts of toughness of mind and body, on the one hand, and the Marxist concept of hegemony as proposed by Antonio Gramsci on the other. According to Gramsci's idea of hegemony (1971 cited in Donaldson 1993), the primary significance lies in the ways in which the ruling class establishes and maintains its domination through the imposition of definitions for any given situation. As such, the majority of the public are led to believe in the sanctity of certain values and practices which are circulated through public discourse. These ruling class dominated discourses have become the primary means of measuring morality and what is considered to be 'normal', 'good' or 'appropriate'. In addition, rather than using direct force or oppressive power, hegemony is able to engage the majority of the population in the process of hegemonisation particularly through the media and social institutions in ways that appear ordinary and natural.

In the Thai context, the possession of qualities associated with being a 'good man' according to the general perception of masculinity or hegemonic masculinity, is of importance. This is especially the case in action films of the post-1997 era in which the art of traditional Thai self-defense, Muay Thai, was incorporated into the representation of Thai masculinity. Rather than being an exotic sport manifesting violence and gambling, Muay Thai in Thai action films operates at a twofold level. Firstly, it projects positive images of Thai men as competent protectors of the motherland to the world and secondly, it allegorically depicts the nation to be small yet strong and unyielding (Kitiarsa 2007). These representations of Thai masculinity are supportive of dominant 
discourses of nationalism. In the psychoanalytic realm, hegemonic masculinity allows the hero access to autonomy and power on the one hand. It also subjects the hero to the universal malady called 'lack' on the other.

\section{2}

\section{Research Objectives}

The objectives of this study are:

1. To find out how the concept of hegemonic masculinity is represented in two Thai action films: Ong Bak (Muay Thai Warrior 2003, dir. Prachya Pinkaew) and The Legend of King Naresuan: The Elephant Duel (2014, dir. Chatri Chalerm Yukol),

2. To explore the action hero's subjectivity through psychoanalytic notions of autonomy and lack,

3. To analyse how class affects the representation of the action hero.

\section{The Context of Thai Masculinity}

Manas Kingchan (personal communication, October 1, 2012), a film archivist, has written in one of his unpublished articles on early Thai action cinema that since the early action film genre emerged out of melodrama, which is kroprot or of mixed genre convention, identification of a film as belonging to the action genre or not was often done by reference to its title, in addition to its narrative. That is to say the titles of early action films are relevant to their generic categorization. Noteworthily, the terms addressing the hero, as shown in the film title, are also indicative of the ideological type of action heroes of a particular epoch. Those terms - nakleng, suphapburut and singh ${ }^{3}$ or suea ${ }^{4}$-, which roughly connote mixed characteristics of a ruffian-like, gentlemanly and brave (and powerful) hero, respectively, recurrently appear in several action films' titles. To give some examples of films in which Mitr Chaibuncha, who is dubbed as a legendary action hero, had acted in: Chao Nakleng (1959, dir. Sek Dusit), Singh Diew (1962, dir. Sor Asananchinda), Singh La Singh (1964, dir. Neramit), Suphapburut Nakleng (1965, dir. Sor Asanachinda). The last mentioned film is of particular interest as its title seemingly reflects a kind of paradoxical hero who possesses both gentlemanly (suphap burut) and ruffian-like (nakleng)

3 The word's literal meaning is lion but this term can also refer to a man who is brave and takes pride in his dignity.

4 The word's literal meaning is tiger and it shares a similar connotation with singh. 
qualities. The normalisation of these terms of reference to the action film hero is critically related to the socio- political context of the period. Years under military dictatorship, from the 1958 coup to the 1973 student's movement, not only led to the production of popular 'escapist' movies which were enjoyed by a wide audience, they also led to the formulation of a type of action hero who is brave, ready to act/fight (singh/suea) and chivalric (suphapburut) or as being equivalently dubbed in Thai as nakleng, as described above. Interestingly enough, it can also be said that the term nakleng is indeed a broadly cultural concept under which suphapburut (the gentleman) and singh/suea (the brave) are generically subsumed. At one point, the term nakleng itself conveyed a negative connotation because it referred to someone (most often a man) who has a tendency to pick fights or gets himself into certain (troubled) confrontations. Hence, the manifestation of the nakleng quality in the film hero is similarly reflected in films bearing these respective terms, nakleng, suphapburut, singh or suea, in their titles.

The connection between being nakleng and masculinity involves different historical origins but one, which is frequently referred to, is pertinent to the leadership of General Sarit Thanarat who served as prime minister between 1958 and 1963. Sarit was said to personify the epitome of nakleng (Keyes 1987, Eowsriwong 2011), who may well be defined as one who is:

[A] person who was not afraid to take risks, a person who lived dangerously, [who was] kind to his friends but cruel to his enemies, a compassionate person, a gambler, a heavy drinker, and a lady killer. In short, the kind of person who represented one central model of Thai masculinity.

Thak Chaloemtiarana Cited in Keyes 1987: 80-81

During Sarit's term in office, martial law was implemented and his decisive policy-making approach, severe measures in suppressing communist rebellion and the executions of men charged with arson earned him notoriety (Keyes 1987: 81). The number of mistresses he had, coupled with his popularly quoted words such as "[ $t]$ he whole responsibility is mine" when exercising political suppression further accentuated his nakleng image. Given such a dictatorial approach in governing the people, Sarit is still publicly remembered for his ability to crack down on crime and foster countrywide development, including the implementation of the first social and economic development plan. Whether we like it or not, Sarit's nakleng image found a resonance in the action film heroes of his period. Rome Rittikrai (Mitr Chaibancha), a masked hero in Chao Nakleng (1959), for instance, was depicted as a Zorro style masked hero whose mission was to help the helpless and defenceless out of their troubles. 
However, it remains a moot question here as to whether the nakleng demeanor well delivered or not.

Pornsak Urutchatchairat, in his how-to pocket book on Thai style leadership, writes that having a nakleng spirit is a significant characteristic indispensable for a good Thai style leader (2012:25). Pornsak maintains that a person of $n a$ kleng spirit is dependable and trustworthy because he is a gentleman who is helpful, having a sporting spirit, never taking advantage of others and yet never letting others take advantage of him. Rapin Praiwan, the hero in the longest popular adventure epic novel, Petch Pra-Uma ${ }^{5}$ (The Diamond of Umadevi) is described as a model of the ideal leader who possesses jai nakleng or the spirit of nakleng in Pornsak's book. As a hunter by profession, Rapin Praiwan is commissioned to find a lost person in the deep forest. He has to lead a small group of people including his commissioners and associate hunters through many dangerous adventures. In different situations, he is shown to enact qualities of virtuosity, bravery, humility, honesty and decisiveness. One example given is that Rapin, as a reputed veteran hunter, is never boastful about his skill and often gives his potential prey, the beast, a chance to attack and survive $(27-28,43)$.

The nakleng characteristics in Petch Pra-Uma's Rapin Praiwan correspond to Nidhi Eowsriwong (2010)'s conception of male protagonist characters portrayed in Thai novels. In his article entitled "Gentleman V.S. Ruffian, Characteristics of Thai Fictional Protagonists" (Phudee VS. Nakleng, Bukkalik Khong Pra-ek Nawaniyai Thai), Nidhi explains that as far as the depiction of Pra-ek or the male protagonist in a Thai novel is concerned, conventionally, there seem to be two contrasting types including a gentleman (phudee) and a ruffian (nakleng). These two types of Pra-ek characters entail differing, clear-cut physical and social manifestations, which can be traced back to early Thai popular novels written by well-known novelists like Gor Surangkanang (Ganha Kiengsiri), Dokmai Sod (Buppha Nimmanhemin) and Riam Aeng (Malai Chupinit), for instance. Physically, whereas the gentleman or phudee type is of compactbuild, slender and appearing somewhat effeminate, the nakleng is portrayed

5 Petch Pra-Uma, written by Pranomtien or Chatchai Wisetsuwannaphoom, is said to be the longest novel in Thailand or perhaps the world. It was initially serialized in a newspaper before being published as a set of 48 pocket books. Based on the story of King Solomon's Mines by H. Rider Haggard, Pranomtien started writing the novel in 1964 and ended the story in 1990, with 12 episodes altogether. The novel has been popular and widely read and the novelist himself was awarded the prestigious "national artist" title in literature in 1997. In addition to the pocket book, Petch Pra-Uma also appears in other versions including 2 comic books and a motion picture (Petch Pra-Uma 1971, dir. Sor Asanachinda). 
as muscular, macho and not effeminate. Such a stark contrast in the physical appearance of the heroes can be observed through Chai Klang, a protagonist in the novel, Ban Sai Thong by Gor Surangkanang and Ruen, a protagonist in Thung Maharaj by Riam Aeng. In social terms, it is explained that the phudee/ gentleman character is associated with being high born, of good family or say, having royal links, meanwhile the nakleng/ruffian reflects a working class background and an unofficial, vernacular way of life. Thus, this makes Chai Klang, a protagonist in Ban Sai Thong, played by Porchet Kaenpetch in its cinematic version, a representative of the phudee protagonist, whereas Ruen in Thung Maharaj, is a nakleng hero. Such a phudee vs. nakleng dichotomy of the male protagonist is made apparent in films of the novels' contemporaneous period. Sor Asanachinda, Kecha Plianvithee and Luechai Naruenat are examples of nakleng embodiment, according to Nidhi.

Given the two differences of the male protagonists, Nidhi argues that when it comes to social relations or social roles, both types of phudee and nakleng share a certain similarity. That is, they are obliged to be a procurer as much as a provider. That they have to contribute to the family economically and establish social credentials or barami for the family of the feudal system is also desirable. While phudee often acquires barami and related power through education and professional connections, nakleng, contrarily, tends to create his own nepotistic clout, whereby his power is gained through social skills and political negotiation. It must be noted that, even though the concept of nakleng connotes a tendency to engage in fighting, this should not be equated with anthapan, or a thuggishness. Nakleng embodies qualities of courage and heroism (jai nakleng spirit) which are absent in an anthapan character.

Despite the binary oppositions of the two types of male protagonists, once the concept of nakleng is deployed in filmic representations, action films in particular, the term nakleng seems to have a positive connotation. At times, as reflected in some action film titles such as Suphapburut Nakleng, it functions to dissolve the distinction between the two categories, suggesting the possibility that nakleng and suphapburut and phudee can be amicably merged with one another. This is to stress that the concept of nakleng should be viewed as a broad cultural conception, rather than a specific definition of the term. In addition, the generic and technological influences of Hollywood on the Thai cinema has in one way or another allowed for possibilities of varying representations of the film hero, which can sometimes go beyond one's cultural familiarity. The masked or disguised hero, who can be gentlemanly and ruffian-like appearing in 1950s Thai action films is a good example here. Therefore, it need not necessarily be a surprise to see the hybridised avatar of a Thai action hero who embodies both nakleng and suphapburut attributes. 
Taking all accounts of the notion of nakleng into consideration, the character of 'nakleng' as manifested in the former prime-minister, Sarit Thanarat, and the adventure hero, Rapin Praiwan, has a few social implications worth mentioning here. First and foremost is that, as the notion of being nakleng connotes how one relates to others in terms of leadership, it implies that a Thai action hero is unlikely to be a solitary individual who accomplishes the mission on his own. He has to mobilize assistance from others by employing his social skills in addition to possessing certain intrinsic qualities. For this, there emerged the stock character of a comedian who acts as the main mobilizer for the hero. In addition to the comedian, other minor characters such as villagers and government officials are also important for the hero's mission particularly in films presenting the right ideology (Sungsri 2004:278-279). Another implication is that the good leadership quality to which the nakleng character is attached requires that the hero must be verbally communicative; hence, the action hero is supposed to be a well-educated man. Even though he should not be boastful, he must be able to communicate effectively when necessary. For this reason, in my opinion, Tony Jaa in all of his action films is lacking in the nakleng quality. He may possess certain requirements such as bravery, humility and honesty which are pronounced in his characterization as represented in Ong Bak (2003) and Tom Yum Goong (2005). Nevertheless, his inability to articulate may well prevent him from getting access to the domain of leadership which is putatively an ideal kind of Thai masculinity. The depiction of King Naresuan (Wanchana Sawasdi) in all sequels of the movie The Legend of King Naresuan, on the contrary, highlights the leadership quality of King Naresuan which encompassed the nakleng demeanor as well. Released at different times after 1997, the depiction of the two outstanding action heroes differ markedly from one another. This is not only to say that these differences are intentional and vital for the cultural verisimilitude of each film which tells stories of two men from totally different backgrounds: the lowly common man for Tony Jaa and the high born king for Wanchana Sawasdi. More importantly, there are some cultural and political connections that deserve our attention, which must be discussed. In addition, a transgender hero, Nong Toom in Beautiful Boxer (2003, dir. Ekachai Uekrongtham) further indicates that the idea of masculinity itself is not a closed and rigid category but rather an open and contentious one.

Nong Toom's alternative sexuality and Tony Jaa's inability to articulate may well put the relation of masculinity vis-à-vis working class men, a category to which both heroes belong, in the spotlight. While I have no intention of bringing the class dichotomy to the forefront, it is worth noting that within the same patriarchal structure, masculinity is allowed to operate differently 
in different social settings. Working class action heroes are allowed to be less "phallomorphic" (Mansfield 2000:70), to use a symbolic term, than those of the middle-class. To illustrate, briefly, the phallomorphic or phallomorphism are terms derived from the psychoanalytic tradition and basically come from the word phallus, literally meaning an erect penis. According to psychoanalysis, the phallus is a symbol of control and power which operates in the symbolic order or our materially mundane world. Our culture, which is masculine and patriarchal in nature, is inherently governed by this kind of phallus which, through language or verbal communication, seeks to influence sexual relations and practices and privileges; those qualities associated with phallic symbolism such as unity, strength, totality and visibility. Hence, when dealing with masculine ideology, the notions of phallus/ phallomorphic/phallomorphism can be of use and relevance as shown in the following discussion. Also, what is interesting to note is that despite a different portrayal of the heroes in each of the films mentioned, they are relatively made to suffer their own phallic pursuits. In the end, what interrupts these phallic pursuits and order and brings completion to the heroes can only be explained within a Buddhist discourse. The discussion below shall also provide different expectations of masculinity through a comparison of the characterization of Muay Thai action heroes, namely, Tony Jaa (Ong Bak trilogy and two parts of Tom Yum Goong) and Asanee Suwan (Beautiful Boxer) with the hero of Historical epic films, The Legend of King Naresuan, $(1,2,3,4,5,6)$, Wanchana Sawasdi. The main focus, however, will be on Tony Jaa and Wanchana who represent notions of hegemonic masculinity although other heroes will also be mentioned.

The traditional theme of action films is often related to maintaining the status quo of the national ideology, particularly as it concerns the three institutions, the nation, the Buddhist religion and the monarch, as Sungsri (2004) has explicated in her research. As such it renders the triumph of the good (the nation) over the bad (the other) pivotal to the film narrative's resolution. Apart from the ideological victory of the nation over the political other, action heroes are also depicted as morally superior to the other. This is consciously done, narratively and cinematically, to support the Buddhist belief in morality. The act of gratitude (khwam-katanyu) is just one, among other Buddhist values, that is considered to be an essential quality of a good man. It is thus a prerequisite, a vital code of conduct to be strictly observed for all heroes regardless of their social background. Critically, the economic breakdown in 1997 which caused 
waves of aftershocks years later has somehow brought khwam-katanyu to the fore. One reason may be that, it is a value pertinent to the discourse of communitarianism and the prevailing sense of nationalism that was resurgent after the recession, and was also taken as a tool, ideologically and pragmatically, to deal with the country's failed economy and the masses' weakened psychology. Social stress resulting from the crisis had an effect on both the rural poor and the urban middle-class alike, albeit differently. However, according to Atinc and Walton (1998), the plight of the poor was more severe because of many relevant factors including the decreasing labour demand, rising commodity prices and social services being cut along with failed crop cultivation as a consequence of drought in some areas (Atinc and Walton 1998: 3). It is said that the economic growth and overall welfare gains that took place in East Asian countries before the crisis proved inadequate in preparing governments for a possible breakdown.

The idea of communitarianism, which is tied to the King Bhumibol's concept of a self-sufficient economy, primarily concerns the invocation of 'the roots' or 'the rootedness' of identity as well as Khon Thai (being Thai) agency. The idea calls for enactment on personal transformation at a fundamental level based on the practice of Buddhist beliefs in moderation, immunisation and pragmatism and the application of the economy or philosophy of selfsufficiency. This was to be followed in order that the individual or the family can successfully get through a difficult time mentally and materially. Given what is said, the process of finding one's own roots resonates differently in two different classes. While the working class and rural subalterns were oriented towards communitarianism, Buddhist values and self-sufficiency, which basically refers to integrative, sustainable farming for household living and living in harmony with a community, the middle-class and the upper class, on the other hand, were ideologically driven to embrace practices of nationalism and protectionism. This is understandable for a small country that has taken pride in its long history of non-colonisation. The economic crisis, which resulted in large scale lay-offs among office workers and the closure of financial institutions and companies, may have been relatively less of a fear than the loss of sovereignty in the sense that the nation had to subject itself to many regulations imposed by the IMF. On the political landscape, critically what emerged were New Social Movements (NSM), led by key figures from different social sectors including those at the grassroots level and state enterprises such as the labour union, the assembly of the poor, social activities groups ${ }^{6}$ and others. Dismayed

6 Nevertheless, the movements were viewed as problematical particularly where their vision on political ideology was concerned. See Kitirianglarp and Hewison, "Botwiphak karnmuang 
by the IMF's imposition on the government concerning economic restructuring regulations, their main commonly shared agenda was to effect a paradigm shift in the direction of economic development away from being internationally dependent and uncritically globalised towards greater self-reliance. This was practiced under the cooperative discourses underpinning the movement including an economy of self-sufficiency, sustainable agriculture, community welfare, community business and Thai wisdom (Kitirianglarp \& Hewison 2009). Notably, these movements not only harnessed a fair share of political power, particularly when they aligned with the nationalist group which had primarily fought for the monarch's challenged sovereignty and against the supremacy of a political party like Thaksin's Thai Rak Thai party, they also raised public awareness of political issues, ushering in political change and, eventually, culminated in the military coup on 19 September, 2006.

To return to the period surrounding the economic crisis on the cinematic front, the sensational reception of three local films Daeng Bailey and the Young Gangsters (1997, dir. Nonzee Nimibutr), Bang Rajan (2000, dir. Tanit Jitnukul) and Nang Nak (2002, dir. Nonzee Nimibutr), all of which were released at the time of the recession testified to the return of the nation. While Daeng Bailey presented young notorious gangsters against the backdrop of retro Thailand, Bang Rajan invoked patriotism through the ancient battle between Thailand and Burma. Similarly, Nang Nak's reimagining of Thailand's past within the social and spiritual context of the Thai middle-class set the tone for the "heritage films" to follow (Ingawanij 2007). To return to the notion of khwam-katanyu or gratitude, the interesting question is how actually it is embraced and conveyed by heroes of the two classes. Fundamentally, the concept of khwam-katanyu was originally derived from the personal relations that exist between parents and children, masters and students or givers and takers. To be regarded as a 'katanyu' person, one is required to return someone else's favour when it is possible to do so. Between parents and their male child, the best act of khwam-katanyu the latter can do towards his parents is to be ordained as a monk. Becoming a monk even for a short period of time is considered important for Buddhist men since it is the opportunity for spiritual purification and the learning of dhamma. That is to say, ordination allows Thai men to perfect their socially required masculine duty. Daeng Bailey and the Young Gangsters, the film that set the trend for the New Thai Cinema, has two sequences that

phak prachachon nai prathet Thai: Khor cham gut khong naew wikror lae yuttasart karnmuang baeb khabuankarn khlaen wai thang sang khom roopbaeb mai" [Critique of "People's Politics" in Thailand: Limitations of analysis and strategic politics of "New Social Movements]", in Fadiewkan (2 April-June 2009: 120-155). 
present the ordination ceremony of the hero, Daeng, both of which are interrupted by his rival gang. The first ordination takes place at the beginning of the film, while his head is being shaved, and the second one occurs toward the end in which he is sitting on an elephant, while the joyful procession is ongoing. Suddenly a gunshot is heard and the lotuses, symbolising purity, fall to the ground. The crowd screams and is dispersed bringing the ceremony to a halt. The failed attempt to be ordained as a novice monk prevents the hero, who later becomes a formidable gang leader, from performing the honourable act of paying gratitude to his mother. Both Daeng and his mother, a prostitute whose most cherished wish is to see her son being ordained a monk, are forever confined to the realm of bhab or sin. Similarly, the transgendered hero in Beautiful Boxer, Nong Toom, is ordained a novice when he is very young. Once he is caught applying a lipstick, Nong Toom has to confide to his novice friend how he desires to have a beautiful feminine body. Nong Toom's revelation is objected to by the fellow novice he is speaking to who warns him that thoughts such as those will result in karmic consequences for his parents. This reflects another dimension of the concept of ordination in that it is merely a path to merit making that one man can give to himself and his parents. Yet, it is not something that justifies all the conduct of an ordained man. In addition to consideration at the individual level, the concept of khwam-katanyu is also deployed on a collective level. On being integrative into the communitarian and nationalist discourses in the wake of the economic crisis, it was required that such awareness must be extended to one's grateful feelings for one's native land. Within such a discourse one was obliged to pay gratitude to his $m a-$ tuphum or motherland in whatever ways possible. ${ }^{7}$ Such an act is commonly referred to as khwam-katanyu tor phandin, meaning the act of paying gratitude to the land.

The concept of gratitude to the land is obviously manifested in Ong Bak, Tom Yum Goong and The Legend of King Naresuan, albeit to varying degrees. In both Ong Bak and Tom Yum Goong, Tony Jaa, who plays a bumpkin-like hero, is determined to take back what has been stolen from his community, namely, the head of a Buddha statute in Ong Bak and two elephants (mother and baby

7 Gratitude to the mother's land is a broad concept which, in addition to the communitarian way of living, involves conservation of natural resources and cultivation of civic consciousness and volunteer spirit. Discourses of both gratitude and gratitude to the motherland were presented and practiced via various channels such as songs, poems, monks' sermons and school and the army projects. See for example, a clip entitled "katanyu tor phandin", 25 February 2014, in Hmong Hub: Music video online. Date Accessed: 20 March 2015 <http://www .lajsiab.com/MnQ3ZZIZ1Z2xsTGcx>. 
elephants) in Tom Yum Goong. The significance of the stolen items is not solely tied to their spiritual and material value for the individual hero but they are also bound to certain collective cultural roots, which are part and parcel of the local history of the community. In the prequels to Ong Bak, namely Ong Bak 2 and $\mathrm{Ong} \mathrm{Bak} 3$, the legend of Ong Bak, the Buddha statute which is regarded by the village people as the god of protection and cultivation, is told. Likewise, the elephant in Tom Yum Goong is also traced back to the career of the hero's ancestors - royal soldiers called 'Jatulangkabaad' whose duty was to protect the king's battle elephant-and it is also the hero's childhood dream to become a Jatulangkabaad soldier. Even though, in a modern context, such an occupation is non-existential, the film implicitly links the past to the present, the traditional to the modern so that the hero's agency and communitarianism can be visibly observed. A connection to one's roots is used to allegorise the moral obligation of the hero (as a representative of the people) to his native land. In Ong Bak, after the hero has succeeded in bringing back the stolen head of Ong $B a k$, he is ordained as part of the village festival. The gratitude he has for his native land is impeccably expressed and it is ceremonially recognised. The ordination ceremony not only functions as a way of celebrating the recovery of the stolen item but serves as an indication of the completion of the paid gratitude. Psychoanalytically speaking, it helps relegate the hero's lack (inarticulacy) to the realm of spirituality, in which the mastery of leadership is not recognised and he is bestowed with a sense power and privilege. More importantly, it is indicative of the village's prevailing sense of history and the collective future of communitarianism.

In King Naresuan, a consciously patriotic film, King Naresuan is shown to have developed a strong connection to his native land ever since he was a young boy and a hostage of the Burmese King, Bayin Naung. Unlike Tony Jaa in Ong Bak and Tom Yum Goong, who is nominated by the village people to defend the communitarian way of life, Wanchana Sawasdi, who acts as King Naresuan is the nominee of the nation. He is thus prefigured to be the ideal nationalist hero who is qualified to lead, rule and perform. He is the sum of the nakleng quality as was aspired to by the former premier, Sarit Thanarat. However, it is his image as a brave, virtuous warrior and his devotion to protecting the people and to strengthening national sovereignty that places him in a superior position, not just his royal status alone. Naresuan's practice of monogamy, in contrast to ancient Thai kings, past rulers and many Thai men of the present time, suggests his approach to modernity, highlighting an ideal feature of masculinity and the nation alike. The first episode of King Naresuan, officially entitled The Legend of King Naresuan: Hostage of Hongsawadi, was 
released in January 2007 under the newly set-up post-coup interim government. In this episode, Naresuan is seen as a young boy, a hostage to Hongsawadi who is already imbued with a strong sense of being Siamese. Given his tender age and monkhood status, he is preoccupied with thoughts of a subservient Ayudhaya, his homeland. The rooster fighting sequences in which the lost rooster of Siam (or Ayudhaya, supposedly belongs to the Siamese hostage) is made to fight against the Burmese rooster and illuminates his intention of fighting for freedom. Against the Buddhist's precept of refraining oneself from causing harm and violence, once young Naresuan finds out about the origins of the rooster, he is no longer reluctant to bring it to the fighting ring. "I doubt the Siamese rooster would ever yield to the Burmese one", he says before taking the rooster to the ring. The first rooster fight ends with victory for the Siamese side leading to further fights. Even though Naresuan is punished by the senior monk for his misconduct, what keeps resonating in his mind is the voice of the Burmese rooster house's owner saying "the fight must happen before freedom is gained". As such, it has led him to bring the rooster to another fight against the one that belongs to Mang Sam Kiet or Bayin Naung's nephew. Surprisingly, this time he is supported by the senior monk, which suggests the certain legitimacy of moral intervention, upon the request that the former must make this rooster fight the final one. Just before the fight begins, upon hearing Mang Sam Kiet's intimidating and insulting words Naresuan responds in a dignified fashion, "given its underdog position, my fighting rooster is Siamese and never retreats from its rival". After the first round, the Siamese rooster appears to be inferior and defeated, so the young prince speaks to the rooster:

If the Siamese blood within you remains strong, you must never give in. Rather, you shall make it evident to the Burmese that no one can frighten the Siamese. You will now bring me victory.

The sequences and quotation elucidated above reveal a few implications that emerge from within and outside the film's narrative. The first implication is that the rooster fight is an analogy of Naresuan's own fate. Like him, the rooster is a Siamese hostage which is destined to fight for its freedom. The fight itself cannot be a one-off competition but will take place many times before true victory is achieved. The invocation of Siamese blood within the fighting rooster is comparable to both the individual (Naresuan himself) and collective invocation of the public audience who are decentered by the political turmoil that happened prior to and at the time of the film's release. The ousted Mr. Thaksin, who was prime minister then, was exposed as having engaged in 
cases of law amending, tax evasion and questionable business dealings that while benefiting his family's businesses, sabotaged the national interest. ${ }^{8}$ The emergence of Naresuan, whose primary concern is the nation's interests, albeit at certain points through territorial expansion and the suppression of hostile states as portrayed cinematically, was much appreciated by middle-class nationalists who felt betrayed by Thaksin and his party. Naresuan's defence of the state's territory, his victorious battle that sets Ayudhaya free from Burmese Hongsawadi bondage rightly entitles him to the badge of the man who is katanyu tor phandin or a man who has repaid a debt of gratitude to his motherland. On a sub-textual level, it also denotes the legitimisation of the coup, or more specifically the military leader, that had actually occurred twice in September 2006 and May 2014 when Naresuan 1 and Naresuan 5 were released respectively. It is important to note that the film, The Legend of King Naresuan: The Elephant Duel (Naresuan 5), was chosen for a free public screening in 160 cinema halls nationwide, on 15th June, 2014, as one activity, among others, in a reconciliation project dubbed "returning happiness to the Thai people". This event, willy-nilly, may be viewed as the implicit political agenda of the film. In terms of leadership masculinity, the image of the latest coup leader, General Prayuth Chan-ocha, who is the current premier, is a case in point here. He is indeed a popular personality among middle-class nationalists due to his nakleng quality: being proactive, decisive, straightforward, morally conscious and yet willing to negotiate. ${ }^{9}$ When such traits are combined with his display of loyalty to the throne and "everything I do, I do it for the country" approach, just like King Naresuan's portrayal on screen, he has probably become one of the most powerful military leaders in the recent history of Thai national politics.

8 There is a large amount of existing materials written about Thaksin's financial irregularities and allegations. One of the most notorious is perhaps his US\$1.9 billion Shin Corp and Singaporean-owned Temasek Holdings transaction. For other charges and more details, see Kaewsan Atipothi, "The Return of Thaksin Regime", August 2011, in Isra News Agency. Date Accessed 22 April $2015<$ www.isranews.org > and also "Check Lists of Thaksin's Inescapable Allegations", 25 November 2014, in Isra News Agency. Date Accessed: 22 April $2015<$ http:// www.isranews.org/58-isranews/isranews-scoop/4390>.

9 Nevertheless, he is also despised by pro-Thaksin and liberal groups who, apart from their anti-coup ideology, have criticised his ruthlessness in handling the anti-coup protests, the use of martial law and the implementation of article 44 in place of martial law and his tough restrictive stance regarding the press. 


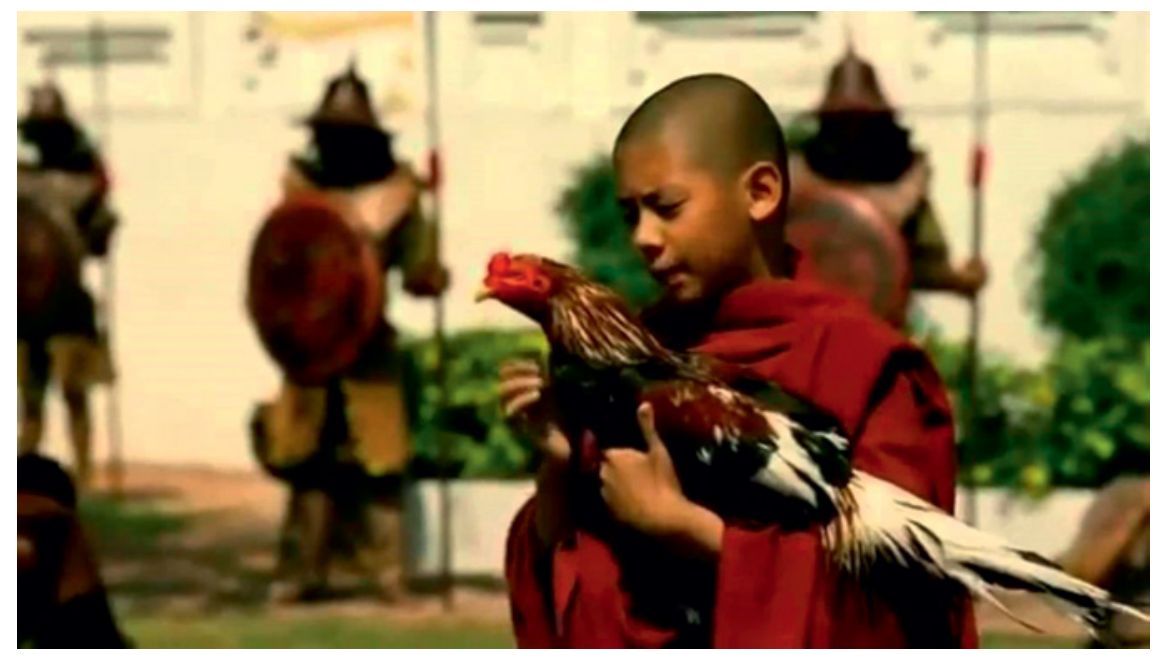

FIGURE 1 Young Naresuan talking to his Siamese rooster (CMV Media 2014)

To briefly explain the two concepts; autonomy is actually a contested concept and can mean different things in various particular contexts. The folk concept of autonomy, for example, suggests a primary desire for freedom regardless of moral concern. Moral autonomy, derived from Kantian tradition, is the capacity to deliberate and to give oneself the moral law, rather than merely conforming to the majoritarian others. Political autonomy is the ability to have one's voice heard and respected within a political context. In this analysis, I would simply approach personal autonomy which can be defied as the individual's capacity to decide for oneself and to pursue one's own course of action (Dryden 2017). For the concept of lack, in Lacanian psychoanalysis, when the subject enters the symbolic order, it has to sacrifice the feeling of oneness it once had in the imaginary realm where the subject has no distinction between itself and other. This entry into the symbolic order results in the subject experiencing a sense of lack and longing for self-completion (Mansfield 2000). To put it differently, it is the process of the child's entry into the social world in which he is subjected to language, conventions and law. The child's relationship with such systematic bodies deprives him of the feeling of completion he used to have, resulting in a sense of lack. From the lack desire ensues, which propels the subject into the symbolic world where we exist. Humans, unfortunately, are drawn endlessly towards desire which is insatiable. However, within the 
Buddhist discourse in which this writing is grounded, lack itself can be compensated for and desire can be contained. Now we shall turn to how masculinity and the ideas of lack and autonomy are intricately played out through the heroic figures in Ong Bak and King Naresuan.

Given different representations of masculinist roles between the middleclass hero and the working class or subaltern individual, there is no conflict of duality between the two. As a matter of fact, the different social classes of the nation should not be seen as being separated by a fixed, rigid divide that causes a great social disparity, rather, if the history of the feudal cultural legacy is considered, class relations are not completely free from their origins in kinship relations, which implies that there is a degree of amicable communication and negotiation between the classes. As such, the differing images of the working class and middle-class hero do not reflect a social or class conflict. Rather, they are related to the segmentation of the targeted film audiences (or say, the masses, multiplex middle-class or cinephiles), all of which look at things differently in their imagining of the nation. Whether it is located in the present or in an historical setting, the depiction of both Tony Jaa as a rural hero and Wanchana as a national hero can be subsumed within the discourse of Buddhist values and spirituality. It is a sphere accessible for identification to all subjects/ citizens. The mastery of Naresuan in the art of war and leadership is important to his autonomy. The same is also applied to Tony Jaa's Muay Thai skills. Being situated within the multiplex's middle- class audience, King Naresuan is there to be gazed upon and recognized as the phallus, the symbol of totality in the political, symbolic order. Unlike the subaltern hero, Tony Jaa, who is ostracized for his sheer lack of voice, ${ }^{10}$ King Naresuan is endowed with leadership qualities that make him the father of the nation. Nevertheless, his phallic power is neither eternal nor transcendent. According to Silverman (1992, cited in Chaudhuri 2006:107), no one can actually possess the phallus or an unattainable wholeness due to universal castration. Throughout King Naresuan's adult life, he is enmeshed in wars with rival states. Any sign of uprising or lack of cooperation from even a small vassal state is promptly translated into 'an act of disloyalty', thus urging him to march out with his army to suppress the resistance. This evidently reflects his ever- present fear of losing his grip on total power. The continual warfare with which Naresuan is engaged, thus, signifies

10 The character of Kham in this film, The Legend of King Naresuan: The Elephant Duel, is a reference to Kham as played by Tony Jaa in Tom Yum Goong. Here Kham, as depicted in this film, is the care-taker of Naresuan's battle elephant, Phra Chaiyanupap. Interestingly, he is portrayed as a dumb, primitive figure whose extraordinary ability of taming and communicating with the wild beast is an accidental discovery. 
his need for the confirmation of his masculinity, given his awareness of the transient nature of victory. In the same way, Tony Jaa in Ong Bak, seeks refuge in the religious domain where his masculine power is fulfilled. For King Naresuan, his masculine power depends on the actions that occur here and now in the material world, or rather, the symbolic world. His every victory in the battle works to conceal his lack, securing the illusion of perfect masculinity. Nevertheless, due to every man's inevitable subjection to "universal castration" as Silverman has rightly claimed, the King's lack is eventually manifested in the film's finale, Naresuan 6 (The Legend of King Naresuan: The Fall of Hongsawadi, 2015) when he is found to be fatally ill. Here, he is bed-ridden due to a malarial fever that he caught during his military forays. This physical fall lends him the final revelation in which death, one form of suffering according to Buddhist philosophy, is endorsed. In one sequence towards the film's end, he says to his wife, Maneechan, "I may have won so many battles, but I'm being defeated by the god of death". Such a revelation as it is shown here is not merely intended to affirm the existence of the universally inevitable lack, which literally suggests one's loss of control over his own fate, rather, it sanctions the superiority of the religious/Buddhist spiritual order to that of the symbolic one.

\section{Conclusion}

As the study has shown, the notion of nakleng contributes significantly to the conception of Thai hegemonic masculinity. Certain qualities such as mastery of fighting skills, bravery, morality and leadership are prioritised. In the two studied films, hegemonic masculinity is manifested in the two heroic figures, Tony Jaa and Wanchana Sawasdi, in similar ways. That is to say they are endowed with some nakleng characteristics, specifically their bravery in fighting for and defending their native lands. Such actions also translate into both of the heroes having khwam-katanyu or gratitude, a moral disposition of good men according to Buddhist spiritual belief. In addition to embodying certain nakleng qualities, the two heroes represent autonomy and lack in a similar fashion, though not in exactly the same. Tony Jaa's autonomy in Ong Bak is harnessed through affinity to his local community. It is the power of communitarianism that comes to play in making him a successful defender. Similarly, craftily executing his military prowess, Wanchana or King Naresuan's capability in redeeming the nation's loss of sovereignty marks him as not merely one of the greatest despots of Thai history but also an ideal figure of hegemonic masculinity. In addition, the two action heroes comparatively suffer from lack, which subjects them to the law of incompleteness or in the psychoanalytic 
sense, the law of universal castration. King Naresuan's leadership qualities and rational outlook seemingly make him superior to the subaltern hero, Tony Jaa, but the former has to suffer an incessant fear of losing power. Likewise, Tony Jaa's lack of voice or inarticulacy deprives him of leadership entitlement, one important marker of the nakleng character. The ordination ceremony of the hero in Ong Bak's end scene, in which the hero renounces the material world to enter to the spiritual realm compensates for this lack. In the same way, King Naresuan, who seems to represent the perfection of the masculinist prototype has to succumb to his untimely death, which presents him with an epiphany about the Buddhist idea of anicca or the impermanence of life. In short, the two heroes in the two action films share some similarities in their making of hegemonic masculinity as far as the nakleng concept and national ideology are concerned. Each of them, albeit being projected as representing different classes of subject/citizen audiences, is depicted, relatively, to catch a glimpse of the totality of his own respective sphere and they suffer, alike, from a certain form of inadequacy.

\section{References}

Atinc, Manuelyan Tamar and Michael Walton. 1998. Responding to the Global Financial Crisis: Social Consequences of the East Asian Financial Crisis. An extended version of the report originally prepared for the Asia Development Forum in March 1998 in Manila. The World Bank Group. Retrieved from http://documents.worldbank.org/curated/en/1998/12/5532918/responding-global-financial-crisis-social -consequences-east-asian-financial-crisis.

Atipothi, Kaewsan. 2011. The Return of the Thaksin Regime. Thai Post Retrieved from http://www.m.rytg.com/s/tpd/1212981 (in Thai).

Chaudhuri, Shohini. 2006. Feminist Film Theorists. London and New York: Routledge.

Donaldson, Mike. 1993. What Is Hegemonic Masculinity?. Theory and Society, Special Issue: Masculinities 22.5: 643-657.

Dryden, Jane. 2017. Autonomy. Internet Encyclopedia of Philosophy. Retrieved from http://www.iep.utm.edu/autonomy/.

Eowsriwong, Nidhi. 2010. Gentleman VS. Ruffian, Characteristics of Thai Fictional Protagonists. Matichon Weekly 30.1575: 22-28 (in Thai).

Eowsriwong, Nidhi. 2011. Ruffian and Godfather and Southern Ruffian. Matichon Weekly 31.1592: 28 (in Thai).

Harrison, Rachel. 2005. Amazing Thai Film: The Rise and Rise of Contemporary Thai Cinema on the International Screen. Asian Affairs 3.3: 321-338. Retrieved from http://www.tandfonline.com/doi/abs/10.1080/03068370500276290. 
Hunt, Leo. 2005. Ong Bak: New Thai Cinema, Hong Kong and the Cult of the "Real". New Cinemas: Journal of Contemporary Film 3.2: 69-84. Retrieved from http://www .intellectbooks.co.uk/journals/view-Article, $\mathrm{id}=5866$.

Ingawanij, Adadol. 2007. Nang Nak: Thai Bourgeois Heritage Cinema. Taylor Francis Online Studies 8.2: 180-193. Retrieved from http://www.tandfonline.com/doi/ abs/10.1080/14649370701295599.

Keyes, Charles F. 1987. Thailand: Buddhist Kingdom as Modern Nation-State. Boulder and London: Westview Press.

Kitiarsa, Pattana. Muay Thai Cinema and the Burden of Thai Men. Asian Research Institute Working Paper Series No. 88, 2007. Retrieved from http://ssrn.com/ abstract $=1317137$.

Kitirianglarp, Kengkij and Hewison, Kevin. 2009. A Critique of "People's Politics" in Thailand: Limitations of Analysis and Strategic Politics of "New Social Movements" Fadiewkan April-June 2: 120-155 (in Thai).

Lewis, Glen. 2003. The Thai Movie Revival and Thai National Identity.Journal of Media and Cultural Studies, 17.1: 69-78. Retrieved from http://dx.doi.org/10.1080/103043102 2000049029.

Mansfield, Nick. 2000. Subjectivity: Theories of the Self from Freud to Haraway. New South Wales: Allen \& Unwin.

Sungsri, Patsorn. 2004. Thai Cinema as National Cinema: An Evaluative History. Doctoral Dissertation, Murdoch University.

Urutchatchairat, Pornsak. 2012. The Art of Leadership from the Best Thai Novel. Bangkok: Nanmeebooks (in Thai).

\section{News Articles from Webpages with No Author}

Check Lists of Thaksin's Inescapable Allegations. November 25, 2014. Isra News Agency. Retrieved from http://www.isranews.org/58-isranews/isranews-scoop/439o (In Thai).

Gratitude to the Land. February 25, 2014. Hmong Hub: Music video online. Retrieved from http://www.lajsiab.com/MnQ3ZIZ1Z2xsTGcx (in Thai).

\section{Image Source}

CMV Media. April 25, 2014. Retrieved from http://www.cmvmedia.com/talk/viewcomment.php?tid $=182 \&$ cat $=$. 